\title{
Extra institutional food consumption and food preferences of full-time public school students
}

\section{Consumo de alimentos extrainstitucionais \\ e preferências alimentares de alunos de escolas públicas de tempo integral}

\author{
Nágila Araújo de CARVALHO1 ${ }^{1}$ 0000-0002-8016-339X \\ Karine Anusca MARTINS2 (iD) 0000-0003-4992-4522 \\ Lucilene Maria de SOUSA ${ }^{2}$ (iD) 0000-0003-1256-8034
}

A B S T R A C T

\section{Objective}

To analyze the factors associated with the consumption of extra institutional foods and the food preferences of full-time students.

\section{Methods}

A cross-sectional study with students from full-time municipal schools in the city of Goiânia, Brazil, from 6 to 14 years of age, both sexes and without food restrictions. The per capita family income, maternal education, nutritional status, the consumption of extra institutional foods (meals not provided by the school) in each meal and their source, and foods with higher or lower preference in school eating habits were verified. Both a Chi-Square and a Linear Trend tests were used to analyze the data.

\section{Results}

Three hundred and fifty nine students participated, most of them aged between 6 and 10. More than one third consumed extra institutional foods (44.0\%), with the highest frequency of consumption during the mid-morning

\footnotetext{
1 Secretaria Municipal de Educação, Diretoria de Administração Escolar, Gerência do Programa de Alimentação Escolar. R. 227, 794, St. Leste Universitário, 74610-130, Goiânia, GO, Brasil. Correspondência para/Correspondence to: NA CARVALHO. E-mail: <nagila_ac@yahoo.com.br>

2 Universidade Federal de Goiás, Faculdade de Nutrição, Curso de Nutrição. Goiânia, GO, Brasil.

Article based on dissertation thesis by NA CARVALHO, entitled "Fatores associados à não adesão e à não aceitação da alimentação escolar por alunos de escolas pública de tempo integral”. Universidade Federal de Goiás; 2015.

Como citar este artigo/How to cite this article

Carvalho NA, Martins KA, Sousa LM. Extra institutional food consumption and food preferences of full-time public school students. Rev Nutr. 2018;30(4):373-84. http://dx.doi.org/10.1590/1678-98652018000400003
} 
snack (34.0\%). These foods mainly originated from their own households $(48.7 \%)$ and one of the main items consumed was carton juice. There was an association between adolescents and mothers with higher education levels and the consumption of these items during lunch, and between students who are non-overweight and their consumption in the afternoon snack. The preferred foods were chocolate milk and bread with butter/ margarine, rice and beans, passion fruit juice, and bread with cheese/requeijão and less preferably: caramelized milk and salt biscuit, beans and beets, coconut porridge and bread with cheese.

\section{Conclusion}

There was a high frequency of extra institutional food consumption, associated to the age group, to a higher educational level of the mother and students who are non-overweight. Foods of higher and lower preference included dairy foods and beans.

Keywords: Food consumption. Food preferences. School feeding.

\section{R E S U M O}

\section{Objetivo}

O objetivo desta pesquisa é analisar os fatores associados ao consumo de alimentos extrainstitucionais e as preferências alimentares de alunos matriculados em escolas públicas de tempo integral.

\section{Métodos}

Trata-se de estudo transversal analítico com alunos de escolas municipais de tempo integral do município de Goiânia (GO). Participaram da pesquisa estudantes de ambos os sexos, com idade entre seis e 14 anos, que não apresentavam restrições alimentares. Verificou-se renda familiar per capita, escolaridade materna, estado nutricional, o consumo de alimentos extrainstitucionais (não provenientes da alimentação escolar) em cada refeição e seu local de origem, bem como os alimentos de maior e menor preferência na alimentação escolar. Utilizou-se teste Qui-Quadrado e Tendência Linear para análise dos dados.

\section{Resultados}

Participaram 359 alunos, a maioria entre seis e 10 anos. Mais de um terço consumia alimentos extrainstitucionais (44,0\%), com maior frequência no lanche da manhã (34,0\%). O principal local de origem desses alimentos foi o domicílio (48,7\%), e um dos principais alimentos consumidos foi o suco de caixinha. Esse consumo, no almoço, associou-se com os adolescentes e as mães com maior escolaridade e, no lanche da tarde, entre os alunos sem excesso de peso. Os alimentos de maior preferência foram leite achocolatado e pão com manteiga/margarina, arroz e feijão, suco de maracujá e pão com queijo/requeijão; os de menor preferência foram leite caramelado e biscoito de sal, feijão e beterraba, mingau de coco e pão com requeijão/queijo.

\section{Conclusão}

Houve frequência elevada de consumo de alimentos extrainstitucionais, associado a faixa etária, maior escolaridade da mãe e alunos sem excesso de peso. Os alimentos de maior e menor preferência incluíram alimentos lácteos e feijão.

Palavras-chave: Consumo de alimentos. Preferência alimentar. Alimentação escolar.

\section{N T R O D U C T I O N}

In the field of food and nutrition public policies, the Programa Nacional de Alimentação Escolar (PNAE, National School Nutrition Program) over the years has achieved important social, economic and political advances aimed at promoting adequate and healthy food for students. Important achievements have been made in the six decades since the creation of the
Program, such as the expansion of the role of the technical leader, the nutritionist; more stringent requirements for the elaboration of menus; and the obligation to purchase food products which come from family-based agriculture. This scenario allowed greater proximity to the pedagogical and teaching-learning aspects in the context of Food and Nutrition Security [1].

Faced with these changes, it is necessary to identify the practical implementation of 
these measures, if they have actually impacted on an improved supply of food and whether students accept the meals offered in public basic education schools. Studies show that there is a significant variation in the acceptance of food preparations served in school nutrition programs of these institutions (27 to 98\%) [2-5] and the better acceptance by students is related to the non-consumption of extra institutional foods and to the participation in food and nutrition education activities. Extra institutional foods are those consumed by students at school and are not part of the PNAE [3].

When considering preferences regarding the type of food or preparations served in school nutrition programs, there is a variation between studies. In general, it is observed a lower acceptance of sweet preparations such as sweet rice $[2,6]$. On the other hand, salty preparations have good acceptability [2].

Despite the free meals offered in Brazilian public schools, students also consume food from other places, especially from home and school canteens $[3,7]$. The studies show that the main extra institutional food consumed were deep fried savouries [7], biscuits [3,7], treats (lollipops/ candies, among others) [3] soda, fruits [3,7] and juices [3]. The consumption of food which are not part of the nutrition program negatively affects its adherence [8].

It is observed that the food preparations that are well accepted are very varied and often the food used as a substitution to the food served in schools are not always healthy, a condition that emphasizes the importance of school nutrition programs as a health promoter in the supply of foods that meet the nutritional needs of the students and encourage the acquisition of healthy eating habits. In addition, current studies are mostly conducted in schools with part-time students.

When considering the importance of a broader knowledge about the PNAE program servicing in the context of full-time schools, this study had the objective of analyzing the factors associated with the consumption of extra institutional foods and preferences in the school nutrition programs of students of full-time public schools of a capital city in the central region of the country.

\section{METHODS}

This is a cross-sectional, analytical study, based on the study "Factors associated with adherence and acceptance of school nutrition programs by full-time public school students", carried out from October to December, 2014. Primary school students participated this study, aged 6 to 14, from full-time municipal public schools in Goiânia, Brazil.

For the definition of the sample, the total number of 4,428 students served by the city's 22 full-time municipal schools was studied, excluding 318 students from two schools, where there were kindergarten students, whose age group (4 to 5 years) was not the scope of the parent study. A total of 4,110 students were considered for simple random sampling based on a frequency of $50 \%$ adherence to the school nutrition program, a margin of error of $5 \%$, a confidence level of $95 \%$, in a total of 351 students, plus an additional 20\% for possible losses.

Each school was part of one of the five Unidades Regionais de Ensino (URE, Regional Education Units) of the City Education Office, according to their geographic location. Therefore, the student quantitative value of the sample was proportionally distributed among $50 \%$ of the full-time schools of each URE, according to their age group (6 to 10 years and 11 to 14 years), to contemplate the different regions of the city.

Students who were present on the day of data collection were included in the study. Those with food-related illnesses who needed a specific diet for their illness (diabetic, hypertensive, 
dyslipidemic, food intolerant or allergic), with mental and physical illnesses that could prevent their participation in the study or were unable to undergo to the measurement of weight and height to evaluate the nutritional status.

A pilot study was carried out in a school with similar characteristics, with approximately $5 \%$ of the sample (19 students), for the application of the research instruments, verification of the time needed to complete each questionnaire and the need for adjustments in the instruments of data collection. At each school, two to three visits were made to introduce the project and verify the students who could participate, according to the inclusion criteria. The students were drawn from each class, proportional to each age group.

The demographic data were sex and age, and the socioeconomic variables were family income per capita (classified in tertiles) and maternal education (classified as 0 to 4 years, 5 to 8 years and $\geq 9$ years), collected with the application of a questionnaire to parents or guardians.

The nutritional status was evaluated through the measurement of the Body Mass Index by age, in which weight and height were collected in accordance to the standardized technique and in duplicate [9]. The anthropometric data were collected by the responsible researcher and by five previously trained research assistants using the Interviewer's Manual. A digital scale, portable, with a precision of $100 \mathrm{~g}$ and a portable stadiometer with a length of two meters, divided in centimeters and subdivided in millimeters, was used. The scores-z were analyzed using the WHO-certified AnthroPlus for Personal Computers software (World Health Organization, Department of Nutrition for Health and Development, Geneva, Switzerland) and classified as severe thinness, thinness, eutrophy, overweight and obesity, according to the World Health Organization criteria [10]. After the frequency analysis in each classification, the nutritional status categories were grouped into "non-overweight" and "overweight".
For each in-school meal, i.e. meal served in schools (mid-morning snack, lunch and afternoon snack), it was verified:

1) The consumption of the school meal (categorized as yes and no) - the student was asked, using the data collection questionnaire, whether or not he/she consumed the meal offered [3];

2) The consumption of extra institutional foods, that is, those consumed by students in school and not from the PNAE (categorized as yes and no);

3) The main extra institutional foods consumed (as reported by at least $10 \%$ of the students);

4) The foods served at school with greater or lesser preference (as reported by at least 10\% of the students).

The association between the consumption of extra institutional foods (yes) and the demographic data, nutritional status and consumption of school meals was analyzed. The source of these foods was also identified.

The data were doubly entered into the Epi Info 7.1.4.0 (Center for Disease Control and Prevention, Atlanta, Georgia, United States) software and checked for inconsistencies. Statistical analyzes were performed in the Data Analysis and Statistical Software version 12.0 (Stata Corporation, College Station, Texas, United States). Chi-Square test or Linear Trend test and Fisher's Exact test were used for analyzes of the association between the consumption of extra institutional foods and the variables consumption of school meal, age group, sex, nutritional status, family income and maternal education. The level of significance was $5 \%$ $(p<0.05)$. The results regarding the foods served in the school of greater and lesser preference were expressed, in descriptive form, in absolute and relative frequencies.

The study was approved by the Research Ethics Committee of the Universidade Federal de Goiás (UFG, Federal University of Goiás), registration code $n^{\circ}$ 799.059/2014. 


\section{RES U L T S}

A total of 359 students participated this study, the majority of whom were in the age group 6 to 10 years-old (73.3\%), classified as "non-overweight" (69.6\%), being members of families of up to four people (67.3\%) and their mothers had $\geq 9$ years of study $(64.5 \%)$. The sex ratio was similar, as was the distribution among the tertiles of monthly per capita income $\left(1^{\text {st }}\right.$ tertile $33.1 \%, 2^{\text {nd }}$ tertile $32.9 \%$ and $3^{\text {rd }}$ tertile $34.0 \%)$.

The students, for the most part, consumed the three meals served $(99.7 \%$ consumed the school lunch, 96.7\% the afternoon snack and $76.9 \%$ the mid-morning snack). The consumption of extra institutional foods was reported by 158 students (44.0\%) and was present at all meals: in the mid-morning snack (34.0\%), at lunch $(13.4 \%)$ and in the afternoon snack (12.5\%). The main source of extra institutional foods was the student's household (Figure 1).

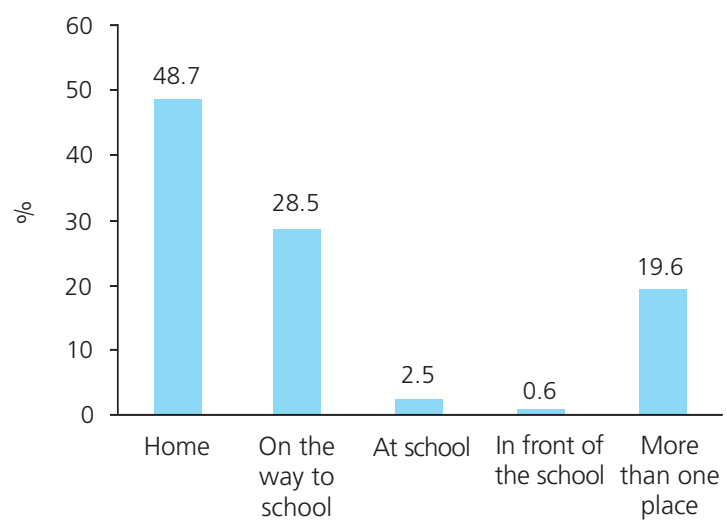

Figure 1. Source of extra institutional foods consumed by students ( $n=158$ ). Goiânia (GO), Brazil, 2014.

Table 1. Extra institutional food consumed in each meal. Goiânia (GO) Brazil, 2014.

\begin{tabular}{|c|c|c|}
\hline Foods consumed in the mid-morning snack $(n=122)$ & $\mathrm{n}$ & $(\%)$ \\
\hline Carton juice & 44 & 36.1 \\
\hline Cheesebread/cheese biscuits & 37 & 30.3 \\
\hline Fruit & 34 & 27.9 \\
\hline Sandwich cookies & 30 & 24.6 \\
\hline Carton chocolate milk/yogurt & 23 & 18.9 \\
\hline Snacks/Chips & 22 & 18.0 \\
\hline Biscuits & 15 & 12.3 \\
\hline Cake & 14 & 11.5 \\
\hline Treats (chewing gum, Brazilian honey bread, brigadeiro) & 14 & 11.5 \\
\hline \multicolumn{3}{|l|}{ Foods consumed in lunch $(n=48)$} \\
\hline Industrialized/carton juice & 26 & 54.2 \\
\hline Fruit & 9 & 18.8 \\
\hline Soda & 8 & 16.7 \\
\hline Food or preparations for lunch & 6 & 12.5 \\
\hline \multicolumn{3}{|l|}{ Foods consumed in the afternoon snack $(n=45)$} \\
\hline Treats (chewing gum, Brazilian honey bread, brigadeiro etc.) & 17 & 37.8 \\
\hline Industrialized juice & 15 & 33.3 \\
\hline Sandwich cookie & 10 & 22.2 \\
\hline Others & 9 & 20.0 \\
\hline Biscuits & 8 & 17.8 \\
\hline Snacks/Chips & 7 & 15.6 \\
\hline Fruit & 7 & 15.6 \\
\hline Carton chocolate milk/yogurt & 5 & 11.1 \\
\hline
\end{tabular}


As for the type of food consumed and referred by at least $10 \%$ of the students, it was verified that the carton juice was present in the three meals, besides the consumption of cheese bread/biscuit in the mid-morning snack; fruit at lunch and treats in the afternoon snack (Table 1).

The consumption of extra institutional foods in the morning snack was not associated with any of the studied variables. At lunch, this intake was higher among students aged 11 or older and among those whose mothers had $\geq 9$ years of education. In the afternoon snack, the non-overweight students had a higher prevalence of the consumption of these foods (Table 2).
The foods served at school with greater preference by students were: chocolate milk and bread/toast with butter/margarine (in the mid-morning snack), rice and beans (at lunch) and passion fruit juice and bread/ toast with cheese/requeijão, a milk-derived product, produced in Portugal and Brazil (in the afternoon snack). The foods of lesser preference were caramel milk and salt biscuit in the morning snack; beans and beets at lunch and coconut porridge and bread with requeijão/cheese in the afternoon snack. It is noteworthy that most of the responses to the foods of lesser preference were at lunch: "No food of preference (likes all of them)" (Table 3).

Table 2. Consumption of extra institutional food and their association to their consumption in each meal, demographic, socioeconomic and nutritional status variables. Goiânia (GO), Brazil, 2014

\begin{tabular}{|c|c|c|c|c|c|c|c|c|c|}
\hline \multirow{3}{*}{ Variables } & \multicolumn{9}{|c|}{ Consumption of extra institutional food per meal } \\
\hline & \multicolumn{3}{|c|}{ Mid-morning snack } & \multicolumn{3}{|c|}{ Lunch } & \multicolumn{3}{|c|}{ Afternoon snack } \\
\hline & $n=122$ & $(\%)$ & $P$ & $n=48$ & $(\%)$ & $P$ & $\mathrm{n}=45$ & $(\%)$ & $p$ \\
\hline \multicolumn{10}{|c|}{ Consumption of the school meal } \\
\hline Yes & 88 & 31.9 & $0.126^{\mathrm{a}}$ & 48 & 13.4 & $1.000^{\mathbf{b}}$ & 43 & 12.4 & $0.652^{\mathrm{b}}$ \\
\hline No & 34 & 41.0 & & 0 & 0 & & 2 & 16.7 & \\
\hline \multicolumn{10}{|l|}{ Age (years) } \\
\hline 6/oct & 93 & 35.4 & $0.362^{\mathrm{a}}$ & 29 & 11.0 & $0.031^{a}$ & 33 & 12.6 & $0.990^{\circ}$ \\
\hline nov/14 & 29 & 30.2 & & 19 & 19.8 & & 12 & 12.5 & \\
\hline \multicolumn{10}{|l|}{ Sex } \\
\hline Male & 59 & 31.7 & $0.348^{a}$ & 21 & 11.3 & $0.230^{\mathrm{a}}$ & 19 & 10.2 & $0.169^{\circ}$ \\
\hline Female & 63 & 36.4 & & 27 & 15.6 & & 26 & 15.0 & \\
\hline \multicolumn{10}{|l|}{ Nutritional status } \\
\hline Non-overweight & 89 & 35.5 & $0.327^{a}$ & 36 & 14.4 & $0.385^{a}$ & 38 & 15.2 & $0.021^{\circ}$ \\
\hline Overweight & 33 & 30.3 & & 12 & 11.0 & & 7 & 6.4 & \\
\hline \multicolumn{10}{|l|}{ Income (tertiles) $)^{\mathrm{d}, \mathrm{e}}$} \\
\hline $1^{\text {st }}$ tertile (until 285 ) & 36 & 30.5 & $0.343^{\mathrm{a}}$ & 11 & 9.3 & $0.070^{c}$ & 15 & 12.7 & $0.887^{\circ}$ \\
\hline $2^{\text {nd }}$ tertile (>285 to 499$)$ & 46 & 39.3 & & 16 & 13.7 & & 16 & 13.7 & \\
\hline $3^{\text {rd }}$ tertile $(\geq 500)$ & 40 & 33.1 & & 21 & 17.4 & & 14 & 11.6 & \\
\hline \multicolumn{10}{|l|}{ Maternal education ${ }^{\mathbf{b}}$} \\
\hline 0 to 4 years & 6 & 27.3 & $0.103^{a}$ & 1 & 4.6 & $0.027^{c}$ & 4 & 8.2 & $0.639^{\circ}$ \\
\hline 5 to 8 years & 44 & 42.3 & & 9 & 8.7 & & 13 & 2.5 & \\
\hline$\geq 9$ years & 71 & 31.0 & & 37 & 16.2 & & 27 & 1.8 & \\
\hline
\end{tabular}

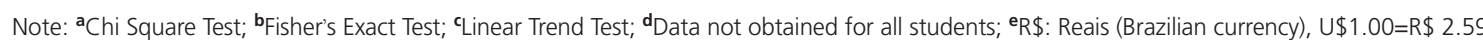
at the moment of data collection. 
Table 3. Foods served in school according to their preference in each meal. Goiânia (GO), Brazil, 2014.

\begin{tabular}{|c|c|c|c|c|}
\hline Meal & Preference & Food & $\mathrm{n}$ & (\%) \\
\hline \multirow{14}{*}{$\begin{array}{l}\text { Mid-morning } \\
\text { snack }(n=276)\end{array}$} & \multirow{8}{*}{ Greater } & Chocolate milk & 92 & 33.3 \\
\hline & & Bread/toast with butter/margarine & 69 & 25.0 \\
\hline & & Bread/toast with requeijão or mozzarella cheese & 62 & 22.5 \\
\hline & & Salt biscuits & 59 & 21.4 \\
\hline & & Cornstarch or milk biscuits & 42 & 15.2 \\
\hline & & Passion fruit juice & 41 & 14.9 \\
\hline & & Coffee with milk & 38 & 13.8 \\
\hline & & Yogurt & 35 & 12.7 \\
\hline & \multirow{6}{*}{ Lesser } & Caramel milk & 53 & 19.2 \\
\hline & & Salt biscuit & 45 & 16.3 \\
\hline & & Bread with cheese/requeijão & 37 & 13.4 \\
\hline & & Baru nut biscuit & 36 & 13.0 \\
\hline & & Coffee with milk & 34 & 12.3 \\
\hline & & Bread with butter/margarine & 34 & 12.3 \\
\hline \multirow{11}{*}{$\begin{array}{l}\text { Lunch } \\
(n=358)\end{array}$} & \multirow{8}{*}{ Greater } & Rice & 201 & 56.1 \\
\hline & & Beans & 182 & 50.8 \\
\hline & & Salad & 155 & 43.3 \\
\hline & & Cow meat & 77 & 21.5 \\
\hline & & Galinhada (dish of rice with chicken) & 71 & 19.8 \\
\hline & & Cooked chicken & 50 & 14.0 \\
\hline & & Fruit & 40 & 11.2 \\
\hline & & Macaroni & 36 & 10.1 \\
\hline & \multirow{3}{*}{ Lesser } & No food of preference (likes all of them) & 51 & 14.2 \\
\hline & & Beans/School beans & 48 & 13.4 \\
\hline & & Beet & 40 & 11.2 \\
\hline \multirow{13}{*}{$\begin{array}{l}\text { Afternoon } \\
\text { snack } \\
(n=347)\end{array}$} & \multirow{8}{*}{ Greater } & Passion fruit juice & 90 & 25.9 \\
\hline & & Bread/toast with cheese/requeijão & 74 & 21.3 \\
\hline & & Yogurt & 50 & 14.4 \\
\hline & & Salt biscuit & 50 & 14.4 \\
\hline & & Bread/toast with margarine & 50 & 14.4 \\
\hline & & Meat sandwich & 45 & 13.0 \\
\hline & & Baru nut biscuit & 41 & 11.8 \\
\hline & & Cornstarch biscuit & 39 & 11.2 \\
\hline & \multirow{5}{*}{ Lesser } & Coconut porridge & 47 & 13.5 \\
\hline & & No food of preference (likes all of them) & 45 & 13.0 \\
\hline & & Bread with cheese/requeijão & 43 & 12.4 \\
\hline & & Baru nut biscuit & 38 & 11.0 \\
\hline & & Salt biscuit & 36 & 10.4 \\
\hline
\end{tabular}

\section{DISCUSSION}

Several students presented the habit of consuming extra institutional foods mainly in the mid-morning snack and these foods were mostly industrialized and coming from the student's home. This consumption was associated with an older school age and a higher maternal 
education at lunch and with those classified as non-overweight in the afternoon snack.

A study carried out in the Southeast region of Brazil found that the consumption of food not provided by the PNAE was reported by almost $80 \%$ of students of municipal and state schools [11], however they were part-time schools and there was no type of discrimination of the food consumed. Regardless of the type of school (part-time or full-time), the consumption of non-PNAE foods can mean the consumption of processed foods, since they are easier to store and transport, besides being attractive for school aged students.

The consumption of processed foods, including soft drinks (such as soda), and treats (candies, chewing gums, chocolates etc.), is considerable among students in Brazil [12-14], especially among adolescents [15]. These foods are considered as "ultraprocessed" by the Food Guide for the Brazilian Population, whose nutritional composition is unbalanced, favoring the excessive consumption of calories and the substitution of in natura or minimally processed foods. Ultraprocessed foods are those made with a wide variety of ingredients including salt, different kinds of sugars, oils, fats and additives which are of industrial use. In contrast to in natura foods, obtained directly from plants or animals, and with the minimally processed ones, where foods are cleaned, dried, peeled etc., not adding salt, sugar, oils and additives, and should form the basis of the Brazilian people food consumption [16].

There was no relation between the consumption of school meals and the consumption of extra institutional foods, even in the midmorning snack, in which the proportion of students who consumed food not coming from the PNAE was higher. In schools in the state of Minas Gerais, it was observed that students who eat such foods tend not to consume food from the school nutrition program [3]. However, it was not evaluated whether this consumption interfered in the frequency, quantity or type of foods consumed in schools, which is an important discrimination for a better understanding of the effects of this relation.

In a study conducted at full-time schools in Piracicaba, Brazil, the results of adherence to food were better, however, the consumption levels for extra institutional foods offered in the canteens was similar to the consumption of school nutrition program items [17]. This reinforces that the school environment, where students stay longer, as is the case with full-time schools, requires more attention, since most of the meals are held there.

Meals served in school must meet the requirements of the legislation governing the PNAE and therefore are healthy and address the nutritional needs of students during the school period [18]. Frequent substitution by other foods, especially those considered as unhealthy ones, or the concomitant use of institutional and extra institutional food, may lead to health damage. In addition, the Program no longer fulfills its role, especially from the educational point of view, in the formation of healthy eating habits. Thus, it is evident the relevance of the evaluation of the quantitative and qualitative consumption of foods by students in schools, considering the intake of food whose source is the institution or not, which may elucidate the inadequate consumption of nutrients.

In the state of Minas Gerais, students from public state schools that did not consume extra institutional foods presented twice the chances of accepting school meals when compared to those who consumed them. Acceptance means that the student likes the food offered at school [3] and this aspect is important, since many food preparations or meals served by schools do not reach the minimum acceptance percentage established in the PNAE $[2,4,18]$. Another study, which was conducted in São Paulo with 83 adolescents from a public school about the students food choices at the institution, identified a low acceptance of school nutrition programs, although many adolescents 
considered it healthy. They also realized that the consumption of food near school or from home was common, competing with the food offered at school [19].

However, this evaluation is scarce in fulltime schools. In a previously published study, with data regarding the acceptance of the meals in the participating schools, it was observed that the acceptance did not reach the minimum established by the legislation (85\%) [4]. Therefore, it is important to respect the eating habits of students, the preparation of attractive foods, the achievement of acceptability tests and the food and nutrition education, in order to promote a better acceptance of school nutrition programs, and to avoid the substitution of school nutrition foods by unhealthy foods or their consumption added to the food served in schools. Food and nutrition education is a field of knowledge and continuous and permanent, transdisciplinary, intersectoral and multiprofessional practice that aims to promote the autonomous and voluntary practice of healthy eating habits [20], an essential factor to favor the implementation of these.

In the present study it was identified that the students consumed, among other foods, treats, industrialized juices, sandwich cookies and snacks. Other studies have identified the consumption of unhealthy foods in Brazilian public schools, such as snacks, treats, lollipops, soda and deep fried savouries $[3,7]$, which highlights and reiterates the importance of the school environment as an essential means of approaching food and nutrition education, with a view to promoting adequate and healthy eating habits, among other topics.

Extrainstitutional foods came mainly from students' homes. In studies that evaluated the consumption of these foods, it was observed that the main sources were the school canteen and the student's home $[3,6,17]$. In the study conducted in two full-time public schools in Piracicaba, it was observed a high prevalence of food consumption in the school canteen
(72.0\%) and a lower proportion of food from the student's home (36.7\%) [17] evidencing, in this case, that the presence of school canteens favored the consumption of extra institutional foods.

The higher consumption of these items, which is observed in the present study, may be related to the fact that there are no canteens in the municipal schools of Goiânia. Bringing food from home when healthy eating is available at school may reflect poor parental understanding of the food served or the PNAE proposal, and the lack of adequate food knowledge and healthy eating habits at home. And even when there is an involvement in the eating habits of the children, it is known that adequate food practices are not guaranteed [21].

In four elementary schools in the state of Washington, United States (US), it was observed that there was a higher consumption of sweetened beverages (30\%) and a lower proportion of milk-based drinks or $100 \%$ fruitbased juices (25\%) between the students who brought food from home $(n=515)$. Students who consumed school meals $(n=509)$ did not consume sweetened beverages at those meals and had a higher consumption of milk-based beverages (64\%). In the US, people have the National School Lunch Program, with free meals, with reduced prices or not, depending on the population group being served [22].

In four schools in Guatemala there was also a high prevalence of sweetened beverages, especially in the public ones [23]. It is a worrying reality the preference for foods in this age group, also observed in the consumption of canned juice in the schools of the present study, especially at lunch and in the afternoon snack, which may represent an excessive consumption of sugar and the perpetuation of inadequate eating habits.

The consumption of extra institutional foods at lunch was higher among adolescents and kids whose mothers have a higher educational level. In full-time public schools 
in Piracicaba, Brazil, it was observed that this consumption was higher among older students and higher-income families when the food came from canteens, and among the younger ones when the food was of household origin [17]. In Campinas, Brazil, among 101 students who consumed extra institutional food from canteens, the majority were from higher income families [24]. This aspect may be related to the fact that higher education is associated with higher income, as observed in the present study among the families of students whose mothers had educational levels higher or equal to nine years, had a higher income (data not shown) and it is likely that these students would have access to a greater variety of foods.

It is recognized in the present study that among the extra institutional foods most consumed at lunch were sweetened beverages, carton juices and soda. It is known that among adolescents, food consumption is in many cases inadequate in relation to energy, vegetables, sugar and fat intake [25]. Moreover, the family environment, with the parents' example and the availability of sweetened beverages at home, favors their consumption in this age group [26], reinforcing the need for educational intervention involving the family.

In the afternoon snack, the highest consumption of extra institutional food was among non-overweight students. The relationship between the nutritional status and the consumption of these foods was observed in full-time schools in Piracicaba, Brazil, where overweight students adhered more frequently during the week to food that could be found in the canteen [17]. Overweight is not only related to food consumption, its cause is multifactorial, involving modifiable factors (sedentarism, behavioral, environmental and breastfeeding) and non-modifiable factors (ethnic, genetic, low or high birth weight) [27].

It can be seen that nutritional status issues are broad and not limited to household or school food consumption, however, a healthy dietary intake should be strengthened in order to cope with overweight issues and any other diet-related illnesses. Thus, more studies are valid and necessary to verify the relationship between nutritional status and the consumption of school nutrition program endorsed food or extra institutional food, especially in the context of full-time teaching.

The most preferred foods by students in the three meals, such as chocolate milk, bread, rice, beans, and juice, coincide with the foods most mentioned in the studies on food consumption carried out with students in Brazil $[28,29]$. A study carried out in São Luiz, Brazil, with 570 fourth to eigth graders identified a high consumption of rice, bread, beans, margarine/butter, beef, flour, biscuits, milk, coffee, vegetables, fruit, processed juices, sweets and chicken [28].

Although there are differences among the different regions of Brazil in relation to eating habits, it is observed that many of these foods are consumed in general by the Brazilian population [30]. This is important since the PNAE recommends that children be offered food that is consistent with the eating habits and local culture [18].

The present study evaluated some aspects of the eating behavior of the students of full-time public schools, for it is understood the real need to take a stand and discuss this topic. However, there were limitations such as not quantifying the consumption of extra institutional foods and school foods at each meal. This assessment could promote a broader understanding of the relationship between school nutrition program and non-PNAE food consumption. Thus, more studies are needed, addressing these and other nuances of the Program in the context of full-time public education.

\section{CONCLUSION}

It was observed that the students consumed food not originated from the PNAE in 
the three meals served at the school, specially ultraprocessed food, with more prevalence in the mid-morning snack and that this consumption was associated to the age and nutritional state of the students and the mother's educational level. Foods of greater and lesser preference included milk, beans and baked goods.

Considering that these students stay longer in school, where most of their nutritional needs must be met, this research is of paramount importance as a subsidy for public managers, in order to advance the Program in Brazil. Although the question of the consumption of extra institutional foods exceeds the scope of the school, going through the familiar, psychosocial and economic, a lot can and must be done. Ensuring the quality of food served having in mind the promotion of healthy eating habits, including food nutrition education in the school context, can minimize the consumption of food considered as unhealthy and work favorably to the frequent consumption of school nutrition program foods.

\section{CONTRIBUTORS}

NA CARVALHO contributed substantially to the conception and design, analysis and interpretation of the data, review and approval of the final version of the article. KA MARTINS and LM SOUSA contributed substantially to the conception and design, interpretation of the data, review and approval of the final version of the article.

\section{RE FER E N C E S}

1. Nogueira RM, Barone $B$, Barros TT, Guimarães KRLSLQ, Rodrigues NSS, Behrens JH. Sixty years of the national food program in Brazil. Rev Nutr. 2016;29(2):253-67. http://dx.doi.org/10.1590/16 78-98652016000200009

2. Cunha DT, Gonçalves HVB, Lima AFA, Martins PA, Rosso VV, Stedefeld TE. Regional food dishes in the Brazilian National School Food Program: Acceptability and nutritional composition. Rev Nutr. 2014;27(4):423-34. http://dx.doi.org/10.15 90/1415-52732014000400004
3. Silva CAM, Marques LA, Bonomo E, Bezerra OMPA, Corrêa MS, Passos LSF, et al. O Programa de Alimentação Escolar sob a ótica dos alunos da rede estadual de ensino de Minas Gerais, Brasil. Ciênc Saúde Coletiva. 2013;18(4):963-9. http:// dx.doi.org/10.1590/S1413-81232013000400008

4. Carvalho NA, Martins KA, Sousa LM, Días MEP. Feeding in full-time public schools: Do students adhere and accept? Rev Nutr. 2017;30(3):357-98. http://dx.doi.org/10.1590/1678-986520170003 00008

5. Raphaelli CO, Passos LDF, Couto SF, Helbig E, Madruga SW. Adesão e aceitabilidade de cardápios da alimentação escolar do ensino fundamental de escolas de zona rural. Braz J Food Technol. 2017;20:e2016112. http://dx.doi.org/10. 1590/1981-6723.11216

6. Cruz LD, Santos JAO, Santos AAO, Gomes ABL, Andrade FAM, Marcellini PS. Análise de aceitação da alimentação escolar dos alunos das escolas municipais urbanas de Itabaiana-SE. Scien Plena. 2013;9(10):1-6.

7. Barros MS, Fonseca VM, Melo MDBB, Chaves CR. Excesso de peso entre adolescentes em zona rural e a alimentação escolar oferecida. Cad Saúde Coletiva. 2013;21(2):201-8. http://dx.doi. org/10.1590/S1414-462X2013000200016

8. Valentim EA, Almeida CCB, Taconeli CA, Osório $\mathrm{MM}$, Schmidt ST. Fatores associados à adesão à alimentação escolar por adolescentes de escolas públicas estaduais de Colombo, Paraná, Brasil. Cad Saúde Pública. 2017;33(10):e00061016. http://dx.doi.org/10.1590/0102-311x00061016

9. Lohmann TG, Roche AF, Martorell R. Anthropometric standardization reference manual. Champaign: Human Kinetics Books; 1988.

10. Onis M, Onyango AW, Borgui E, Siyam A, Nishida C, Siekmann J. Development of a WHO growth reference for school-aged children and adolescents. Bull World Health Org. 2007;85(9):660-7.

11. Rocha NP, Filgueiras MDS, Albuquerque FM, Milagres LC, Castro APP, Silva MA, et al. Análise do programa nacional de alimentação escolar no município de Viçosa, MG, Brasil. Rev Saúde Pública. 2018;52:16. http://dx.doi.org/10.11606/ S1518-8787.2018052007090

12. Corrêa RS, Vencato PH, Rockett FC, Bosa VL. Padrões alimentares de escolares: existem diferenças entre crianças e adolescentes? Ciênc Saúde Coletiva. 2017; 22(2):553-62. http://dx. doi.org/10. 1590/1413-81232017222.09422016

13. Longo-Silva G, Menezes RCE, Souza CAN, Marinho PM, Toloni MHA, Oliveira MAA. Factors associated with regular consumption of obesogenic foods: 
National school-based student health hurvey, 2012. Rev Nutr. 2016;29(5):609-33. http://dx.doi. org/10.1590/1678-98652016000500001

14. Ferreira NL, Claro RM, Lopes ACS. Consumption of sugar-rich food products among Brazilian students: National School Health Survey (PeNSE 2012). Cad Saúde Pública. 2015;31(12):2493-504. http://dx.doi.org/10.1590/0102-311X00014515

15. Costa CS, Flores TR, Wendt A, Neves RG, Assunção MC, Santos IS. Comportamento sedentário e consumo de alimentos ultraprocessados entre adolescentes brasileiros: Pesquisa Nacional de Saúde do Escolar (PeNSE), 2015. Cad Saúde Pública. 2018;34(3):e00021017. http://dx.doi.org/10. 1590/0102-311X00021017

16. Geraldi MV, Leite IQ, Pinto SN, Diez-Garcia RW. Pictorial instrument to guide the classification of foods in the dietary Guidelines for the Brazilian Population. Rev Nutr. 2017;30(1):137-44. http:// dx.doi.org/10.1590/1678-98652017000100013

17. Danelon, MS. Programa de alimentação escolar em unidades de tempo integral: experiências e desafios de gestão [dissertação]. Piracicaba: Universidade de São Paulo; 2007.

18. Ministério da Educação (Brasil). Resolução CD/ FNDE/ n.26, de 17 de junho de 2013, dispõe sobre o atendimento da alimentação escolar aos alunos da educação básica no âmbito do Programa Nacional de Alimentação Escolar - PNAE. Diário Oficial da União. 2013 [acesso 21 set 2015]. Disponível em: https://www.fnde.gov.br/ fndelegis/action/UrlPublicasAction.php

19. Leme AC, Philippi ST, Toassa EC. O que os adolescentes preferem: os alimentos da escola ou os alimentos competitivos? Saúde Soc. 2013;22(2):456-67. http://dx.doi.org/10.1590/sausoc. v22i2.76444

20. Ministério do Desenvolvimento Social e Combate à Fome (Brasil). Secretaria Nacional de Segurança Alimentar e Nutricional Marco de referência de educação alimentar e nutricional para as políticas públicas. Brasília: Ministério do Desenvolvimento Social e Combate à Fome; 2012.

21. Mayer APF, Weber LND, Ton CT. Perfis parentais com base nas práticas educativas e alimentares: análises por agrupamento. Psicol Saúde Doenças. 2014;15(3):683-97. http://dx.doi.org/10.15309/14 psd150310

22. Bergman EA, Englund T, Ogan D, Watkins T, Barbee $M$, Rushing $K$. Beverage selections and impact on Healthy Eating Index Scores in elementary children's lunches from school and from home. J Child Nutr Manage. 2016 [cited 20 Apr 2018];40(1):118. Available from: https://schoolnutrition.org/ uploadedFiles/5_News_and_Publications/4_The_ Journal_of_Child_Nutrition_and_Management/ Spring_2016/5-BeverageSelectionsandlmpact.pdf

23. Godin KM, Chacón V, Barnaya J, Leatherdale ST. The school environment and sugar-sweetened beverage consumption among Guatemalan adolescents. Public Health Nutr. 2017;20(16):2980-7. http:// dx.doi.org/10.1017/S1368980017001926

24. Danelon MS, Fonseca MCP, Silva MV. Preferências alimentares no ambiente escolar. Segur Alim Nutr. 2008;15(2):66-84.

25. Manouchehri MM, Jafari S, Fouladgar M, Heidan K, Farajzadegan MF, Karami $\mathrm{P}$, et al. Nutritional knowledge, practice, and dietary habits among school children and adolescents. Inter J Prev Med. 2014;5(Suppl2):S171-8.

26. Watts AW, Miller J, Larson NI, Einsenberg ME, Story MT, Neumark-Sztainer D. Multicontextual correlates of adolescent sugar-sweetened beverage intake. Eat Behav. 2018;30:42-8. http://dx.doi.org/ 10.1016/j.eatbeh.2018.04.003

27. Nunes AA, Nunes MSS, Silva ASM, Marques L. Obesidade na infância. Pediatr Mod. 2015;51(7):263-72.

28. Conceição SIO, Santos CJN, Silva AAM, Silva JS, Oliveira TC. Consumo alimentar de escolares das redes pública e privada de ensino em São Luís, Maranhão. Rev Nutr. 2010;23(6):993-1004. http:// dx.doi.org/10.1590/S1415-52732010000600006

29. Levy RB, Castro IRR, Cardoso LO, Tavares LF, Sardinha LMV, Gomes FS, et al. Consumo e comportamento alimentar entre adolescentes brasileiros: Pesquisa Nacional de Saúde do Escolar (PeNSE), 2009. Ciênc Saúde Coletiva. 2010;15(Suppl2):3085-97. http://dx.doi.org/10.15 90/S1413-81232010000800013

30. Souza AM, Pereira RA, Yokoo EM, Levy RB, Sichieri R. Alimentos mais consumidos no Brasil: Inquérito Nacional de Alimentação 2008-2009. Rev Saúde Pública. 2013;47(Supl1):190S-9S. http://dx.doi.org/ 10.1590/S0034-89102013000700005

Received: May 2, 2018

Final version: August 24, 2018

Approved: September 24, 2018 